The Canadian Journal of Higher Education

La revue canadienne d'enseignement supérieur

Volume XXXI, No. 2, 2001 pages $1-46$

\title{
Rurality and Capital: Educational Expectations and Attainments of Rural, Urban/Rural and Metropolitan youth
}

\section{LESLEY ANDRES \& E. DIANNE LOOKER}

The University of British Columbia \& Acadia University

\section{ABSTRACT}

This paper uses data from two longitudinal surveys of Canadian youth to examine the effects of rural versus urban/rural and metropolitan residence on young people's educational expectations and attainments. The surveys are based in British Columbia (B.C.) and Nova Scotia (N.S.), two provinces that have very different systems of postsecondary education. B.C. has an articulated system with formal structures which allow students to take the first two years of university study at a community college before transferring to a university. N.S. has no such formal transfer system. Its community college system is not well developed but it has a large number of universities, some of which are in rural areas. The findings show that, in both provinces, students in rural areas have lower expectations and attainments compared to other students, even when parental background, gender and academic stream are controlled. A comparison across provinces shows that rural youth in B.C. are more

\footnotetext{
* The authors would like to acknowledge the support received from the Social Science and Humanities Research Council of Canada in the form of a strategic research grant in the theme area of Education and Work in a Changing Society. The grant has enabled the co-investigators to develop a collaborative network in order to compare and contrast their longitudinal data sets. Also, we acknowledge the support of the Social Science and Humanities Research Council of Canada and the B.C. Council on Admissions and Transfer in funding our individual longitudinal research projects.
} 
likely than their N.S. counterparts to pursue postsecondary education, but rural N.S. youth are more likely to have successfully completed a degree program four to five years after high school. Implications of these findings for future research as well as for policy changes in the two provinces are discussed.

\section{RÉSUMÉ}

Cette recherche utilise des données de deux études longitudinales portant sur les jeunes Canadiens pour examiner les effets du lieu de résidence (rural, urbain/rural, métropolitain) sur les attentes éducatives et la réussite scolaire des jeunes. Les sondages ont été menés en ColombieBritannique et en Nouvelle Écosse, deux provinces qui ont des systèmes d'études supérieures différents. La Colombie-Britannique a un système articulé avec des structures formelles qui permettent aux étudiants de suivre leur deux premières années d'études universitaires au collège avant de transférer dans une université. La Nouvelle Écosse n'a pas ce système de transfert formel. Son système collégial n'est pas bien développé mais il existe dans cette province un grand nombre d'universités, dont quelques-unes sont situées dans les régions rurales. Les résultats indiquent que, dans ces deux provinces, les étudiants des régions rurales ont des attentes et des niveaux de réussite plus bas en comparaison avec les autres étudiants, même quand le milieu familial, le genre et le parcours scolaire sont contrôlés. Les comparaisons entre les provinces indiquent que les jeunes des régions rurales en Colombie-Britannique sont plus susceptibles que leurs pairs en Nouvelle Écosse de poursuivre des études supérieures, mais les jeunes des régions rurales en Nouvelle Écosse sont plus susceptibles de compléter avec succès un programme de premier cycle quatre à cinq années après le secondaire. Les implications de ces résultats pour des recherches futures de même que pour des modifications de politique dans les deux provinces sont discutées. 


\section{INTRODUCTION}

Geographic location has long been identified as one of the factors affecting whether and where youth participate in postsecondary education. Individuals living in non-urban areas have been identified as "under-represented" in institutions of higher education (Commission on the Future Development of the Universities of Ontario, 1984; Fortin, 1987; Pike, 1970; Report of the B.C. Provincial Access Committee, 1988; Siemens, 1965a, 1965b; Stephenson, 1982). Provincial efforts such as the establishment of universities in rural areas, the creation and expansion of community college systems, and the development of alternate methods of program delivery (e.g., open learning institutions) have been introduced, in different ways and varying degrees, to increase the educational levels of rural populations However, few comparative studies exist to assess how the structure of the postsecondary system influences participation by rural, urban/rural, and metropolitan youth. This paper examines the impact of geographic location on the educational expectations and attainments of youth from two different Canadian educational systems.

The structure of a given postsecondary system is a critical but often overlooked dimension in studies of access to postsecondary education. Opportunities for access to and completion of postsecondary studies may depend on the nature of the system and institutional arrangements such as articulation with the secondary system and between various types of institutions within the postsecondary system. The availability of postsecondary institutions can facilitate or constrain young people's perceptions and eventual decisions about after high school options.

In this paper, we compare educational expectations and attainments of youth from metropolitan, urban/rural, and rural communities of British Columbia (B.C.) and Nova Scotia (N.S.). We focus on these two provinces because of their dissimilarity; that is, they represent opposite ends of the continuum of postsecondary systems in Canada. In British Columbia, through sophisticated articulation arrangements between its community colleges, university colleges, universities, and institutes, the postsecondary system aims to promote a seamless passage among the 
various levels and forms of postsecondary offerings. In contrast, the early establishment of universities of Nova Scotia has resulted in a postsecondary system rich in universities, but with limited links among types of postsecondary institutions.

Although the structure of the postsecondary system is an important determinant of postsecondary participation, numerous other factors influence access to and participation in postsecondary education by adolescents from different geographic locations The majority of existing research is U.S.-based, and focuses on students' individual attributes and subsequent "choices." Several studies have demonstrated that rural youth have lower educational aspirations and plans as compared to urban youth (Cobb, McIntire, \& Pratt, 1989; Hanson \& McIntire, 1989; Sarigiani et al., 1990). However, lower levels of aspirations and expectations by rural youth are explained in a variety of ways.

Some authors maintain that because of differences in rural and nonrural labour markets, students from rural communities have limited exposure to a wide range of educational and career opportunities (Haller \& Virkler, 1993; Hektner, 1995; Sarigiani et al. 1990). According to Haller and Virkler (1993), since "adolescents aspire to what they know or can imagine" (p. 171), limited exposure may lead to depressed educational, and hence occupational aspirations The aspirations and expectations of these individuals, particularly young people who are anticipating their adult roles, are constrained by what they define as available and possible (Andres, 1993; Looker \& MacKinnon, 1997). Others argue that rural youth are confronted with the apparent reality that "moving up" means "moving out" (Hektner, 1995). Whereas metropolitan youth face a wider range of postsecondary options (Andres \& Krahn, 1999), none of which require them to leave home, for rural youth the decision to continue on to postsecondary studies cannot be disentangled from the decision to leave the family home and community of residence (Looker, 1993). That is, in order to achieve upward social mobility, individuals must leave their rural communities (Hektner, 1995). Those who wish to remain close to home may be more likely, in terms of educational attainment and eventual occupational status, to have lower aspirations and expectations. This line of reasoning is extended to students living in 
urban/rural areas who fall somewhere in between; their "choices" may be driven by the willingness and ability of the individual to leave home and the community (Donaldson, 1990; Hektner, 1995).

Although the fact of growing up in a particular geographic location may have a major impact on the post-high school outcomes of youth, it is not simply a matter of "choosing" whether to remain in one's rural community of residence or leave for a more urbanized setting. It also involves adjusting one's educational aspirations and expectations accordingly. Since social, cultural, and economic forces have major effects on how individuals gain access to the system, it is important to monitor the effects of such structural barriers to postsecondary participation as low socio-economic status on educational expectations and attainments.

Numerous studies have concluded that postsecondary participation is highly correlated with educational and occupational background of parents, academic program undertaken in high school, and gender (Andres, Anisef, Krahn, Looker, \& Thiessen, 1999; Anisef, 1980; Guppy, 1988; Guppy \& Pendakur, 1989; Looker, 1993; Porter, et al., 1982). In a study of the effects of community of residence on the educational and occupational postsecondary aspirations of high school seniors from five different demographic settings in southern Ontario, O'Neill (1981) demonstrated that students from rural farm areas and villages had the lowest levels of postsecondary educational aspirations of all geographic groups. He concludes that "continuous indoctrination into traditional rustic values, coupled with parental support" (p. 61) may discourage students from village and rural farm areas from aspiring to postsecondary study. Using a large, nationally representative U.S. data base (High School and Beyond), Haller and Virkler (1993) found that approximately half of the variance in educational aspirations between rural and nonrural youth difference could be attributed to differences in socioeconomic status.

From a cultural reproduction perspective as advanced by Bourdieu $(1979,1986)$, the transmission of capital, in the form of cultural as well as economic resources, occurs at the level of the family. That is, parents transmit capital in the form of dispositions, habits, and attitudes, to their children. Such transmission results in the reproduction of the dominant culture through which background inequalities are converted into 
differential academic attainments and eventually social status. Moreover, gendered dispositions have been described as another form of capital (McCall, 1992). Rather than treating gender as a secondary determinant to educational and occupational status, McCall claims that it is important to examine the "interaction of gender with class distinction through the lens of embodied capital" (p. 839). Hence, the various forms of capital are reproduced as advantage or disadvantage. Such a process provides opportunities for the transformation of and resistance to external constraints, and symbolizes the extent to which human actors exercise agency.

Together, individual characteristics, geographic location, and the structure of a provincial postsecondary system can be conceptualized as simultaneous forces acting upon individuals and upon which individuals act. At the core are forms of individually held capital, such as parental education, income, status, and encouragement which, if used by parent and child, can enhance or inhibit certain options. Educational capital possessed by parents can be transformed into useable resources by the child in the form of skills, knowledge, networks and values. We would argue that communities provide another level of influence, in terms of resources and the symbolic worth they place on the individual and family capital. As Dragastin and Elder (1975) note, "young people do not live in the total society; they spend their lives in... neighbourhoods, schools, communities" (p. 19). Communities as well as families shape definitions of "people like us." Hence, different degrees of urbanization may be related to aspirations and expectations about postsecondary attendance and attainment.

Finally, the structure of the postsecondary system defines the realm of possibilities in terms of postsecondary institutions and availability of offerings. The proximity of postsecondary institutions, possession of the requisite cultural capital, and proclivity toward higher education intersect to either facilitate or constrain access to and completion of postsecondary studies. 


\section{PURPOSE OF THE STUDY}

The purpose of this study is to compare the educational expectations and attainments of rural, urban/rural, and metropolitan youth from two Canadian provinces. We begin by describing the Nova Scotia and British Columbia systems of postsecondary education. Then, using panel data, we examine the educational expectations of these young adults. The wide range of postsecondary institutions located throughout British Columbia leads us to expect some differences in the expectations of rural, urban/rural, and metro youth. However, we predict that these differences will be much less pronounced than in Nova Scotia, where there is no formally articulated postsecondary system. Because our longitudinal data sets permit us to conduct analyses over time, we are also able to determine educational expectations and attainments four to five years after high school.

We are also interested in determining the influence of different forms of capital on youth from different geographic regions. By determining whether differences in expectations and attainments by B.C. and ns rural, urban/rural, and metro youth exist by parental levels of education, curricular stream in high school, and gender, we are able to both assess the impact of these social structural variables on educational expectations and eventual completion patterns, and determine whether the influence of social structural factors differ by province.

\section{The British Columbia and Nova Scotia Contexts}

In Canada, education falls strictly under provincial, rather than federal jurisdiction. Given this fact, the structure of postsecondary institutions varies considerably by province. From the outset, the community college system in British Columbia was designed to offer "two-year academic programmes for students who will either transfer to degreegranting institutions or will complete their formal education at this level" (Macdonald, 1962, p. 51). In the meantime, British Columbia has evolved into an articulated system of postsecondary institutions in which detailed formal arrangements exist. Because inter-institutional agreements permit students with appropriate prerequisites earned at community colleges to 
transfer to universities with recognized credit, the system is intended to promote equality of opportunity by allowing a seamless flow of students toward their educational and occupational goals. In this way, rural, urban/rural, and metropolitan students can take the first part of their university education at a more locally accessible community college, and then for their senior years move on to a university, typically located in a large metropolitan centre. Transferability of credit is documented in the B.C. Transfer Guide, and students intending to transfer are expected to select courses that are deemed transferable by the receiving institution.

For B.C. youth graduating from high school in 1988, the postsecondary system offered a full range of choices' including five public universities, one private university, fourteen community colleges, four public institutes, an Open University and an Open College, as well as hundreds of private colleges and trade schools. Also, since 1990, six community colleges have been transformed into university colleges and offer university degrees in some program areas.

In contrast, the Nova Scotia system of higher education has focused on promoting access to university-level education. As Christie (1997) points out, although Nova Scotia boasts more universities per capita than in any other province, it also has the least developed community college system in Canada. According to Christie, the following factors have contributed to high university participation rates in Nova Scotia:

widespread geographic dispersion of the universities, their reputation for offering quality education with personal attention, and a sense of community, the long tradition of university attendance for major parts of the provincial society, generous admission requirements at some universities and a financial regime that in the early and mid-1980s gave tremendous incentive for enrollment growth. (p. 241)

Unlike B.C., community colleges are relatively new to Nova Scotia. Although other non-university postsecondary institutions have existed for some time (e.g., a nautical institute, a geographic college), community colleges as such have existed only since 1988. At that time, the existing vocational secondary schools were revamped and transformed into community colleges. Hence, Nova Scotia does not have any 
formalized provision for transfer credit from community colleges to universities. Although specific community college courses may be accepted at particular universities for credit, this transfer is negotiated on a caseby-case basis; there are no formal transfer arrangements. ${ }^{2}$

As of 1989, the Nova Scotia higher education system was comprised of eleven degree-granting institutions and a newly created multiplecampus community college. Given their recent development, such colleges would not be as much a part of the common experience of young people, their parents or their guidance counselors as one would expect in other regions of the country.

\section{DATA AND MEASURES}

The data for this analysis are generated from two longitudinal surveys of youth, one based in British Columbia, on Canada's west coast, the other from Nova Scotia, in the east. The two surveys differ in design and size, but are comparable in a number of ways. Using similar questions, both ask young people in their late teenage years about their educational expectations. In both studies, the same youth are contacted four to five years later for information on their educational attainments to date and their educational expectations as young adults. Both surveys include information from rural, urban/rural, and metropolitan youth, allowing the comparisons which form the central basis of this paper.

The data allow an analysis not only of the amount of education young people expected and obtained, but also the type of postsecondary education they pursued and attained. Although it has been argued that Canada's postsecondary system was designed to be deliberately heterogeneous and pluralistic to meet the diverse needs of a pluralistic society (Alberta Advanced Education, 1984), considerable evidence links university attainment with higher occupational status and increased earning power (Allen, 1997; Anisef, Ashbury, \& Turittin, 1992; Breneman \& Nelson, 1981). There is growing recognition among researchers (Andres, 1995; Dwyer, 1995; Dwyer et al., 1997) of the importance of differentiating between types of postsecondary education. Minimally, a "university versus other" distinction should be made. 
The British Columbia study commenced in 1989 and was designed to document patterns of postsecondary participation. The first phase involved a mailed questionnaire sent to a selective sample of 1988 high school graduates $(\mathrm{N}=5,345)$ and focused on the post-high school choices they had made. The sample was generated from Ministry of Education records. High school and postsecondary records that provided demographic and institutional information were linked to the survey data. This set of data provides Time 1 information for the British Columbia sample. In 1993, a mailed follow-up of the 1989 sample was conducted, with responses received from over 2,000 of the original respondents. Information was received from postsecondary participants and non-participants in all seventy-five school districts in British Columbia. Only those who responded to both surveys are included in this analysis $(\mathrm{N}=2,030)$. Approximately $36 \%$ of this total graduated from high schools located in metropolitan areas, $52 \%$ from urban/rural areas, and $24 \%$ from rural areas of the province (see Andres, 1995 for details).

The Nova Scotia sample involves not a school cohort but a birth cohort. Names and addresses of youth born in 1971 were obtained from school boards in five regions of Nova Scotia, including rural and urban/rural areas as well as Halifax (one of the few urbanized areas of the province). School leavers and graduates were included, as were the majority still in school in 1989, the time of the first survey (see Looker, 1993 for details). Given the lack of systematic information on the geographic distribution of age cohorts in Nova Scotia, the sample was selected to be as representative as possible of the province's overall population. According to the 1986 census, about half of Nova Scotians lived in urban areas. There is no corresponding information on numbers in rural versus what we have called 'urban/rural areas.' Detailed structured interviews lasting an hour to an hour and a half were conducted with those respondents who agreed to participate ( $88 \%$ of those eligible). Over 400 metropolitan, 130 urban/rural and 260 rural respondents were part of the final sample. ${ }^{3}$ Questions included several focusing on the young people's educational plans and expectations. In 1994 the same individuals were contacted via a mailed questionnaire; responses were obtained from 685 of the original respondents. As in the British 
Columbia study, information was gathered on the youths' educational attainments to date and their educational expectations at this stage in their lives. In order to parallel the British Columbia sampling frame as much as possible, only high school graduates $(\mathrm{N}=550)$ were included in the Nova Scotia part of the Time 2 analysis. In total, the N.S. sample included $52 \%$ metropolitan, $16 \%$ urban/rural, and $32 \%$ rural youth.

It is important to point out that the samples were drawn differently. The Nova Scotia sample was a purposive sample of areas, with random sampling from lists within the chosen school areas. The British Columbia sample was a stratified selective sample generated from Ministry of Education data files. For the purposes of this analysis, key differences will be identified by direction and size of relationships and consistency in patterns, keeping in mind that some subgroups in certain analyses have fairly small "Ns". ${ }^{4}$

\section{MEASURES}

\section{Dependent variables}

Central to the current analysis are questions about the youths' educational expectations and attainments. In the B.C. sample, the 1989 respondents were asked to declare the highest level of education they expected to obtain; in 1993 they were asked the same question, thus giving a measure of their expectations at two points in time. The 1989 sample of youth from ns were asked a similar question about the highest level of education they realistically expected to obtain, and in 1994 respondents provided information about their expected education at that time.

The 1993 respondents from British Columbia were asked to provide the name of all postsecondary institutions attended, by year, in each of the five years following high school graduation. They also provided detailed information about each educational credential earned. The 1994 Nova Scotia respondents identified the highest level of education they had currently completed. Although the time frames are slightly different for the two studies, the follow-up measure which identified the type of institution attended in both is four or five years after high school. 


\section{Independent variables}

There are numerous ways to measure geographic location. These measures include community size or school district size (McCracken \& Barcinas, 1991; Schonert, Elliott \& Bills, 1991), type of community (e.g., farm, rural non-farm, village, small town and large city) (O'Neill, 1981), or a combination of both (Cobb, McIntire, \& Pratt, 1989; Haller \& Virkler, 1993; Hanson \& McIntire, 1989; Sewell \& Orenstein, 1965; Van Hook, 1993). In other studies, rurality is defined purposively (Conroy, 1997; Edwards \& McKinnon, 1987; Hektner, 1995; Siemens, 1965a, 1965b). However, Pike (1970) points out that two measures of community of residence - proximity to postsecondary institutions and community size - are relevant to an examination of postsecondary participation and completion patterns Pike and others (Beezer \& Hjelm, 1961; Conference of Ministers of Education of European Member States of UNESCO, 1963) have demonstrated the relationship among the presence of a postsecondary institution in a community, size of community, and postsecondary participation.

British Columbia and Nova Scotia differ considerably in size. To capture these differing dimensions of community of residence and to address geographic differences within each province, our three categories of geographic location - metropolitan, mixed urban/rural, and rural - are determined according to whether a degree granting or degree transfer institution was within reasonable commuting distance. Such a measure is particularly relevant to a discussion of rurality and educational attainment. In this case, we define rurality in terms of access to resources - including access to university-level courses. There are, of course, other resources that metropolitan areas offer, including more job options, ${ }^{5}$ public transportation, and a range of private and public sector services.

The non-metropolitan school areas in Nova Scotia represent the four economic regions outside the Halifax-Dartmouth metropolitan area. Two of the eleven school districts in the study, Antigonish and Glace Bay (with 52 and 75 respondents respectively in 1989; 32 and 42 in 1994), have a university within their catchment area. Respondents from these areas are classified as "urban/rural" in the current analysis. Almost $90 \%$ 
of the other non-metropolitan respondents (classified in this paper as "rural") have access to a community college within the school district. Virtually all are within 100 kilometres of some postsecondary institution.

The British Columbia sample includes a larger number of respondents who are classified in terms of their access to either a university per $s e$ (in the metropolitan areas of Vancouver and Victoria) or a community college (which offers transfer credit to a university). Respondents were classified in terms of the geographic distance from the nearest university or community college, with those more than 100 kilometres away considered "rural"; those between 50 to $100 \mathrm{~km}$. away (i.e., within reasonable commuting distance) were classified as "urban/rural".

In summary, our measure involves the following classifications: (1) "metropolitan" to refer to those respondents with access to university level courses and other urban resources, (2) "urban/rural" for those with access to university level courses, but not the full range of other urban resources, and (3) "rural" for those with access to neither universitylevel courses nor other urban resources. ${ }^{6}$ In the western sample, communities with community colleges are classified as urban/rural; in the eastern sample, the corresponding communities are classified as rural, reflecting the lack of institutionalized transfer credit between community colleges and universities in Nova Scotia.

Gender is a key independent variable, with a straightforward self-classification as the measure. Parental education is used as an indicator of family socioeconomic status. Although there are several ways to operationalize this variable, the measure "parental education" is in keeping with the perspective that suggests that advantage is transmitted through the family (Bourdieu, 1986). Also, respondents were more likely to know precise details about parents' education than, for example, about family income. And as Guppy and Pendakur (1989) point out, both parents do not necessarily work in paid employment situations. Hence, whereas information on each parents' occupational status and income is more difficult to attain, information on both the mother's and father's education can be more readily obtained and employed in analyses. The study operationalizes this variable by categorizing parents into two groups: one or both parents with an earned university degree, or neither parent with a degree.? 
The final independent variable we will be considering is type of program completed in high school. This is a dichotomous variable; either individuals completed an "academic" or a "non-academic" high school program. Academic programs provide students with the prerequisites for university admission; non-academic programs do not. In British Columbia, this information was obtained from official school records, and in Nova Scotia the respondents reported the details of their school program in the 1989 interviews.

\section{RESULTS}

We begin this analysis by examining the overall distribution of respondents in the two research sites on the central dependent variables. Are rural youth less likely than metro youth to expect to pursue some form of postsecondary education? Are those in British Columbia (with access to universities via transfer credit) more likely to expect to attend university? Does the pattern of expectations change from the teenage years to the time of the follow-up surveys when respondents were in their early twenties? What regional differences exist in the actual educational paths taken by these youth? And finally, do postsecondary completion rates differ depending on geographic location of origin? The first set of tables allows us to address these questions.

Table la depicts youths' expectations at Time 1 - one year after high school for the western sample, and during high school for the eastern sample. The main point to note is that for both samples, geographic location has an effect on expectations. Those youth in rural areas are less likely than others to expect to study beyond high school. In both studies, almost $90 \%$ of youth, regardless of geographic location, expect to obtain some level of postsecondary education. However, a large difference is seen in the proportion expecting to obtain some non-university education; $33 \%$ of rural respondents in B.C. compared to about a quarter of those from the metropolitan or urban/rural areas give this response. The difference in Nova Scotia is greater with $35 \%$ of rural compared with $11 \%$ of metropolitan youth expecting to earn a non-university credential. In both studies, rural youth are less likely than others to expect to 
Table 1a

Time 1 - Highest Level of Education Expected

\begin{tabular}{|c|c|c|c|c|c|c|c|c|}
\hline & \multicolumn{4}{|c|}{ British Columbia } & \multicolumn{4}{|c|}{ Nova Scotia } \\
\hline & $\begin{array}{c}\text { Urban } \\
\% \\
\mathrm{~N}=706\end{array}$ & $\begin{array}{c}\text { Urban/rural } \\
\% \\
\mathrm{~N}=997\end{array}$ & $\begin{array}{c}\text { Rural } \\
\% \\
\mathrm{~N}=238\end{array}$ & $\begin{array}{c}\text { Total } \\
\% \\
\mathrm{~N}=1,941\end{array}$ & $\begin{array}{c}\text { Urban } \\
\% \\
\mathrm{~N}=276\end{array}$ & $\begin{array}{c}\text { Urban/rural } \\
\% \\
\mathrm{~N}=84\end{array}$ & $\begin{array}{c}\text { Rural } \\
\% \\
\mathrm{~N}=167\end{array}$ & $\begin{array}{c}\text { Total } \\
\% \\
N=527\end{array}$ \\
\hline High school or less & 11 & 12 & 16 & 12 & 7 & 10 & 17 & 11 \\
\hline Non-university & 23 & 24 & 33 & 25 & 11 & 17 & 35 & 20 \\
\hline Bachelor Degree & 32 & 28 & 26 & 29 & 49 & 61 & 37 & 47 \\
\hline $\begin{array}{l}\text { Prof. or Graduate } \\
\text { Degree }\end{array}$ & 35 & 36 & 25 & 34 & 33 & 13 & 11 & 23 \\
\hline
\end{tabular}

Table $1 \mathrm{~b}$

Time 2 - Highest Level of Education Expected

\begin{tabular}{|c|c|c|c|c|c|c|c|c|}
\hline & \multicolumn{4}{|c|}{ British Columbia } & \multicolumn{4}{|c|}{ Nova Scotia } \\
\hline & $\begin{array}{c}\text { Urban } \\
\% \\
\mathrm{~N}=692\end{array}$ & $\begin{array}{c}\text { Urban/rural } \\
\% \\
N=958\end{array}$ & $\begin{array}{c}\begin{array}{c}\text { Rural } \\
\% \\
N=233\end{array} \\
N=2\end{array}$ & $\begin{array}{c}\text { Total } \\
\% \\
\mathrm{~N}=1,833\end{array}$ & $\begin{array}{c}\text { Urban } \\
\% \\
N=246\end{array}$ & $\begin{array}{c}\text { Urban/rural } \\
\% \\
\mathrm{~N}=70\end{array}$ & $\begin{array}{c}\text { Rural } \\
\% \\
N=139\end{array}$ & $\begin{array}{c}\text { Total } \\
\% \\
\mathrm{~N}=455\end{array}$ \\
\hline High school or less & 3 & 3 & 5 & 4 & 5 & 1 & 8 & 5 \\
\hline Non-university & 25 & 29 & 42 & 29 & 24 & 24 & 38 & 29 \\
\hline Bachelor Degree & 30 & 28 & 25 & 28 & 24 & 24 & 23 & 24 \\
\hline $\begin{array}{l}\text { Prof. or Graduate } \\
\text { Degree }\end{array}$ & 42 & 40 & 29 & 32 & 46 & 50 & 31 & 42 \\
\hline
\end{tabular}




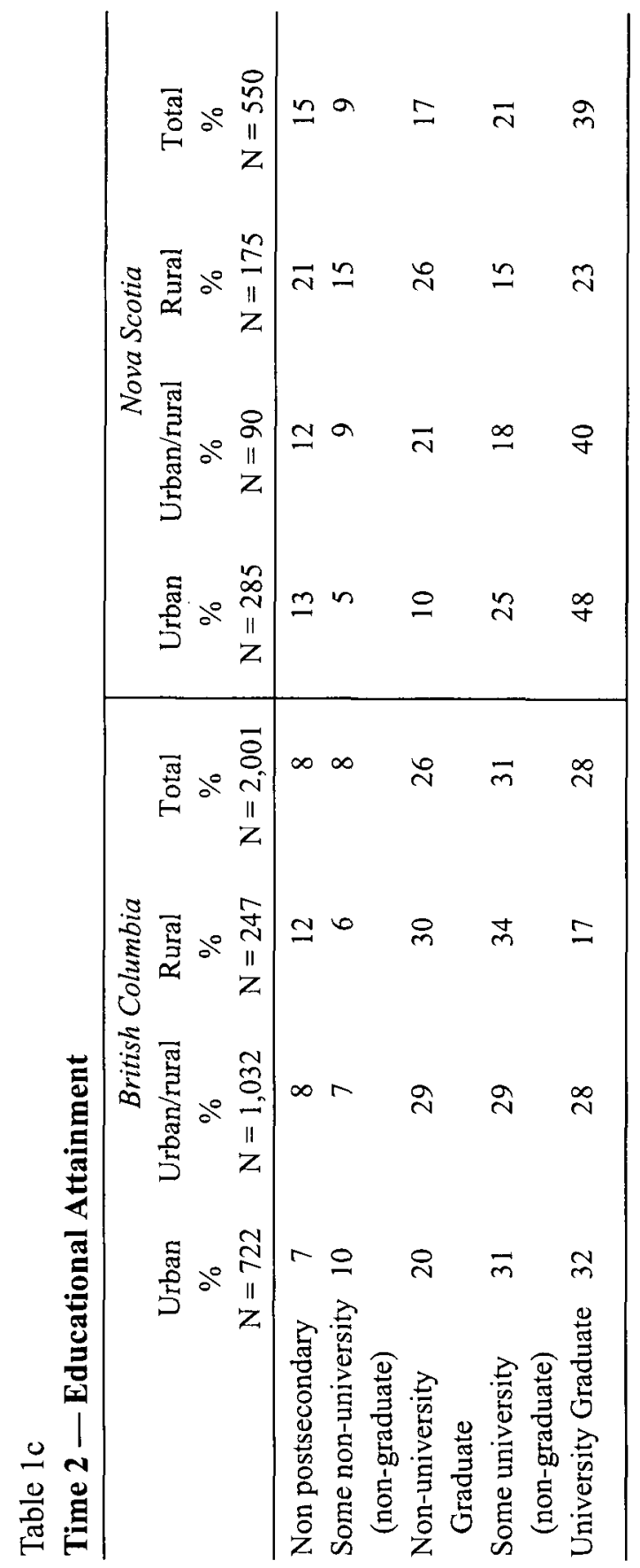

The Canadian Journal of Higher Education

Volume XXXI, No. 2, 2001 
complete a university degree. In Nova Scotia, ease of access does seem to play a role in that both those in the metropolitan and urban/rural categories are more likely than the rural students to expect to obtain at least one university degree. However, compared to the B.C. rural sample, rural N.S. youth are equally likely to expect to terminate their studies at the high school or non-university level.

Overall, more respondents in British Columbia indicate an expectation to go beyond a first undergraduate degree to some post-graduate or professional training. ${ }^{8}$ If we focus on just those who plan to obtain this advanced level of education, we see that in British Columbia the responses are similar for the urban/rural and the metropolitan youth. In Nova Scotia, the urban/rural numbers resemble those of the rural respondents. ${ }^{9}$

In summary, although the expectations of these youth are quite high, rural youth in both regions have lower expectations than those in metropolitan or urban/rural communities. For the most part, urban/rural youth are as likely as metropolitan youth: (1) to expect to go to some postsecondary institution, (2) to expect to complete a university degree and (3) in British Columbia but not Nova Scotia, to expect an advanced degree. Next we examine how these expectations change over time.

Table $\mathrm{lb}$ portrays the level of the respondents' expectations at the time of the follow-up surveys. At Time 2 , even fewer youth $-5 \%$ or less in both sample areas - report that they expect no more than high school. Table $1 \mathrm{~b}$ reveals high levels of expectations for graduate or professional degrees, up from the figures in Table la, particularly for the Nova Scotia youth. Overall, the pattern of responses within the table is very similar to those for their earlier expectations. Rural youth have lower expectations than the other respondents. They are less likely to expect a graduate or professional degree; they are more likely to expect their highest level of education to be at some non-university institution.

A major shift of note is the fact that in the Time 2 data, the responses of the urban/rural youth are consistently similar to those of their metropolitan counterparts in both British Columbia and Nova Scotia. This pattern was less consistent in the Time 1 data. This pattern suggests that access to a university, either directly by location of a university in the community, or indirectly via transfer credit from a community college, 
may provide young people in the area with a view of university and even graduate education as a realistic possibility. The absence of this visible option may curb the expectations of rural youth. The question that remains is how these expectations translate into attainments. The results at the time of the two follow-up surveys, in 1993 and 1994, are depicted in Table 1c.

Table 1c portrays the educational paths these youth actually followed. The central question is whether there is a difference by geographic location. We see a large difference in Nova Scotia for the lowest educational category, "no postsecondary education." Whereas $21 \%$ of the rural ns youth did not continue further than high school, $13 \%$ or less of the urban/rural or metropolitan youth fell into this category in 1994. These rural N.S. youth were also more likely to have gone to a non-university institution and less likely than their more metropolitan counterparts to have completed a university degree. In terms of this measure of educational attainment, the "urban/rural" category seems to be a middle ground for the youth in both studies. Nevertheless, some provincial differences are apparent. ${ }^{10}$ In terms of university completion, urban/rural youth in B.C. and N.S. resemble the metropolitan respondents. However, when examining the proportions completing non-university studies, urban/rural youth from both provinces are more like their rural counterparts. The important point here is that geographic location does make a difference.

It is intriguing that Nova Scotia youth are as likely as British Columbia respondents to attend university. Given the sampling frames used, we might expect more of the B.C. youth to have gone to university. This pattern shows itself only in the rural areas; $51 \%$ of rural B.C. youth compared to just $38 \%$ of the Nova Scotia youth obtained at least some university education. In comparison, $63 \%$ of metropolitan respondents in B.C. and $72 \%$ of metropolitan N.S. respondents have taken some university level courses; the corresponding figures for the urban/rural youth are almost identical (B.C. $-57 \%$, N.S. $-58 \%$ ).

Given that all B.C. respondents had completed high school by 1988 and hence would have had more time than Nova Scotia youth to complete their degree programs, we would have expected to find higher numbers of B.C. youth having earned bachelors' degrees. This, however, 
is not the case. As Table 1c depicts, N.S. youth were more likely to have obtained university degrees. This difference is most pronounced in the categories of "metropolitan" ( $48 \%$ N.S. versus $32 \%$ B.C. respondents) and "urban/rural" ( $40 \%$ of N.S. versus $28 \%$ of B.C. youth). The urban/rural British Columbia students took university-level courses, but were less likely than their Nova Scotia counterparts to have completed a degree program. For B.C. youth, factors such as the need to transfer to other postsecondary institutions, problems related to transfer between community college and university, and resulting longer periods of study may explain low university completion rates by these young people five years after high school graduation (Andres, 1995; Andres, Qayyum, \& Dawson, 1997; Andres, 1998; Andres \& Krahn, 1999).

To summarize this section, we have found persistent differences in both educational expectations and attainments among the geographical sub-areas in each sample. The general pattern of rural youth having lower expectations and attainments than those in other areas is apparent. If access to university-level courses were the only issue, the urban/rural youth should be like the metropolitan group in terms of the numbers expecting and obtaining higher levels of education. Although this pattern is evident in our data, some interesting and important variations appear. Most intriguing is the relatively low percentage of metropolitan and urban/rural youth in B.C. who have completed a university degree by the time of the follow-up survey.

Beyond establishing the importance of geographic location in understanding young people's educational expectations and attainments, we wish to understand how and why growing up in a rural community has this impact. To what extent are the different forms of capital that youth from different geographic regions possess reflected? We examine this question by comparing the expectations and attainments of metropolitan, urban/rural and rural youth in the two samples, controlling for parental education and stream in high school. We also control for gender, not because it will vary across sub-regions (we expect as many males as females in each of the areas), but because the impact of geographic location on expectations and attainments may differ for women and men. 


\section{Parental education}

First, we examine the effect of controlling for parental education. Table 2 a reports the relevant results. By comparing the top and bottom panels of the tables, the first thing to note is that family-based capital in the form of parental levels of education does have an impact on both the expectations and the attainments of respondents. More of those youth whose parents had graduated from university expect to attend university themselves, and more of them do so. Also, individuals in this group expect and obtain post-graduate education. Fewer persons go beyond high school, and fewer expect to and in fact register in non-university programs as compared to university programs.

Our focal question now is whether rural location affects these expectations and attainments, once parental education is controlled. In both British Columbia and Nova Scotia, proportionately more parents in the rural areas have lower levels of education than parents in urban areas. Perhaps the lower levels of expectations and attainments among rural youth simply reflect capital transmitted by the family.

Table 2 a demonstrates that this is simply not the case for all youth in terms of expectations at Time 1. In both samples, geographic location has little effect on the educational expectations of those with highly educated parents. Considering only those respondents with one or more parents holding university degrees, approximately $80 \%$ of B.C. youth and $84 \%$ of Nova Scotia youth from all geographic categories expect to earn bachelors degrees or more. However, the pattern for youth whose parents have not completed university is quite different. In this group, rural youth are less likely than those from other areas to expect to attend university and they are considerably less likely to expect to obtain graduate or professional education. Approximately $60 \%$ of B.C. youth without university-educated parents from metropolitan and urban/rural areas expect to complete undergraduate degrees or more; only $44 \%$ with similar parental backgrounds from rural areas expect to accomplish the same level of education. The pattern is more dramatic for Nova Scotia youth. The comparable figures are as follows: approximately $70 \%$ of respondents from metropolitan and urban/rural areas versus $40 \%$ from rural areas expect to earn bachelors degrees. The other part of this picture is 


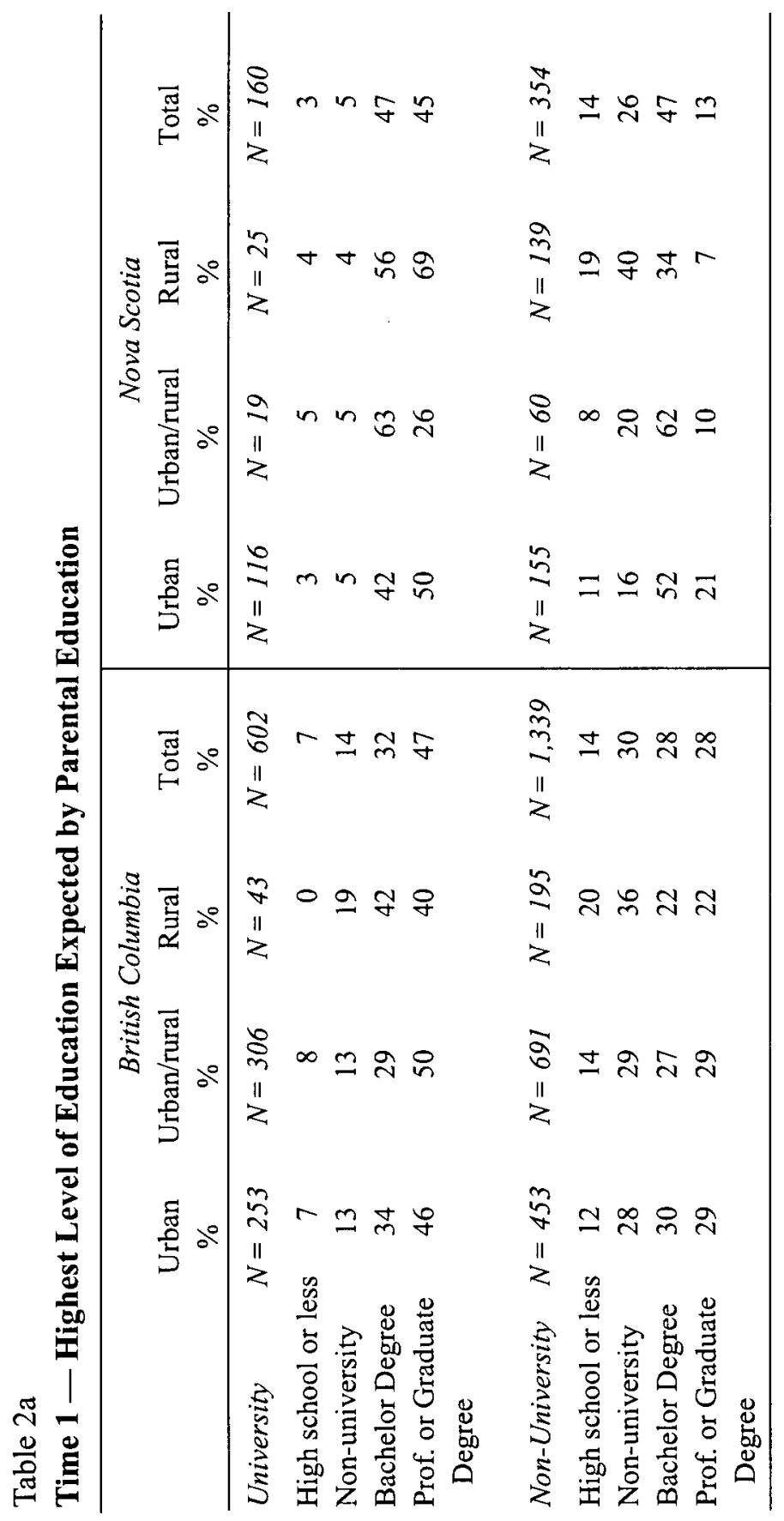

The Canadian Journal of Higher Education Volume XXXI, No. 2, 2001 


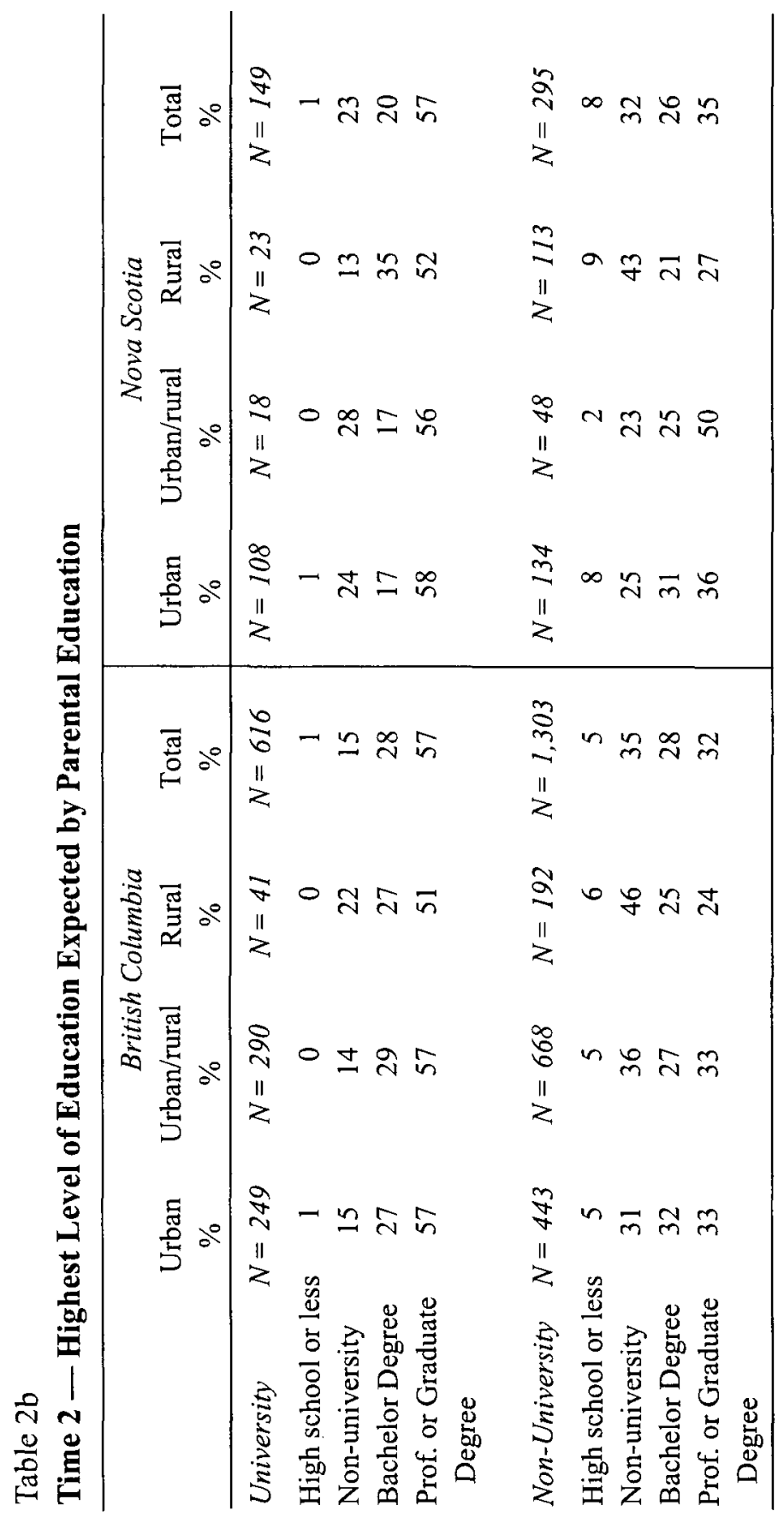

The Canadian Journal of Higher Education

Volume XXXI, No. 2, 2001 
Table 2c

Time 2 - Educational Attainment by Parental Education

\begin{tabular}{|c|c|c|c|c|c|c|c|c|}
\hline & \multicolumn{4}{|c|}{ British Columbia } & \multicolumn{4}{|c|}{ Nova Scotia } \\
\hline & $\begin{array}{c}\text { Urban } \\
\%\end{array}$ & $\begin{array}{c}\text { Urban/rural } \\
\%\end{array}$ & $\begin{array}{c}\text { Rural } \\
\% \\
\end{array}$ & $\begin{array}{c}\text { Total } \\
\% \\
\end{array}$ & $\begin{array}{c}\text { Urban } \\
\% \\
\end{array}$ & $\begin{array}{c}\text { Urban/rural } \\
\% \\
\end{array}$ & $\begin{array}{c}\text { Rural } \\
\% \\
\end{array}$ & $\begin{array}{c}\text { Total } \\
\% \\
\end{array}$ \\
\hline University & $N=257$ & $N=309$ & $N=44$ & $N=610$ & $N=121$ & $N=19$ & $N=27$ & $N=167$ \\
\hline High school or less & 2 & 3 & 2 & 2 & 4 & 5 & 4 & 4 \\
\hline Some non-university & 12 & 13 & 7 & 12 & 3 & 11 & 4 & 4 \\
\hline $\begin{array}{l}\text { Non-university } \\
\text { graduate }\end{array}$ & 14 & 18 & 25 & 17 & 2 & 5 & 7 & 3 \\
\hline Some university & 28 & 29 & 30 & 28 & 30 & 21 & 30 & 29 \\
\hline University graduate & 44 & 39 & 23 & 41 & 61 & 58 & 56 & 60 \\
\hline Non-University & $N=465$ & $N=723$ & $N=203$ & $N=1,391$ & $N=123$ & $N=55$ & $N=135$ & $N=314$ \\
\hline High school or less & 11 & 10 & 14 & 11 & 20 & 14 & 24 & 20 \\
\hline Some non-university & 9 & 4 & 5 & 6 & 5 & 9 & 16 & 10 \\
\hline $\begin{array}{l}\text { Non-university } \\
\text { graduate }\end{array}$ & 23 & 34 & 32 & 30 & 16 & 23 & 29 & 22 \\
\hline Some university & 33 & 30 & 36 & 32 & 21 & 17 & 13 & 17 \\
\hline University graduate & 25 & 23 & 13 & 22 & 39 & 37 & 18 & 30 \\
\hline
\end{tabular}


that rural youth from homes without university-educated parents in Nova Scotia and British Columbia are more likely to expect to go to some non-university postsecondary institution. In both studies, the pattern of expectations for urban/rural youth are very like those for metropolitan youth, regardless of level of parental education.

Table $2 b$ shows the effect of geographic location on educational expectations at Time 2, controlling for parental education. Again, the dominant pattern is evident: geographic location does have an effect, but this effect is mitigated by parents' educational levels. For B.C. youth with university-educated parents, educational expectations remain high, with a slightly greater proportion of rural youth expecting to complete a non-university education, and slightly fewer expecting to earn a graduate degree. The pattern is somewhat different for Nova Scotia youth with similar parental backgrounds. More N.S. rural youth expect to complete a bachelors degree and only slightly fewer expect to complete graduate or professional studies. However, B.C. and N.S. youth from homes where neither parent has earned a university degree are less likely than their metropolitan and urban/rural counterparts to expect to complete university.

The test, in terms of actual educational attainments, is portrayed in Table 2c. Those most likely to have at least some university education (72\%) are metropolitan youth in British Columbia whose parents attended university. Those least likely to have some university education $(31 \%)$ are those in rural Nova Scotia with less educated parents. Within these two extremes, the general patterns hold. Rural youth have lower levels of educational attainment than others; those with highly educated parents have higher levels.

In other words, the differences reported in Tables la through 1c do not simply reflect differences across sub-regions in levels of parental education. Parental education does influence both expectations and attainments, but it does not explain away the variation when geographic location is introduced into the analysis, particularly for youth from homes with low parental educational attainment. It is clear that familial capital in the form of parental education influences the educational decisions of their children, but geographic location appears to have an 
additional effect. When comparing children from families with similar amounts of cultural capital, rural youth have different expectations and attainments than those from more metropolitan areas. In B.C., youth from more highly educated families across all geographic categories attend university in approximately equal proportions. However, rural youth are half as likely as metropolitan youth to complete their university studies. Attendance and completion patterns are similar for B.C. youth from families with low levels of parental education, with few rural students completing university studies.

The exception to the overall pattern is Nova Scotia youth from rural areas with university-educated families. Approximately equal proportions of rural and metropolitan youth attend and complete university. More youth from urban/rural areas in Nova Scotia complete non-university and university programs, and fewer fall into the "some university" category.

\section{Academic program}

The next set of tables (Tables 3a, 3b, and 3c) demonstrate the relationship between geographic location and educational expectations and attainments, controlling for the youth's academic program while in high school. The Nova Scotia study started with a smaller sample size than the British Columbia study. Sample numbers within the sub-areas decrease with sample attrition in Time 2 and with the introduction of this control variable. Comparison of individual percentages should therefore be interpreted with caution, particularly for the N.S. results.

The overall pattern comparing those in the academic to those in the non-academic program is predictable. Those having graduated from academic programs have higher expectations at Time 1 and Time 2, and they report higher levels of educational attainment. That is, fewer of them expect to and do limit themselves to secondary levels of education; more of them expect and obtain a university and a post-graduate education. In general, more of those in the Nova Scotia study are in the academic stream in high school; in each province, more of the metropolitan youth are in this higher-level program.

Within each of the two types of academic program, rural youth have lower levels of educational expectations at Time 1 (Table 3a) and Time 2 


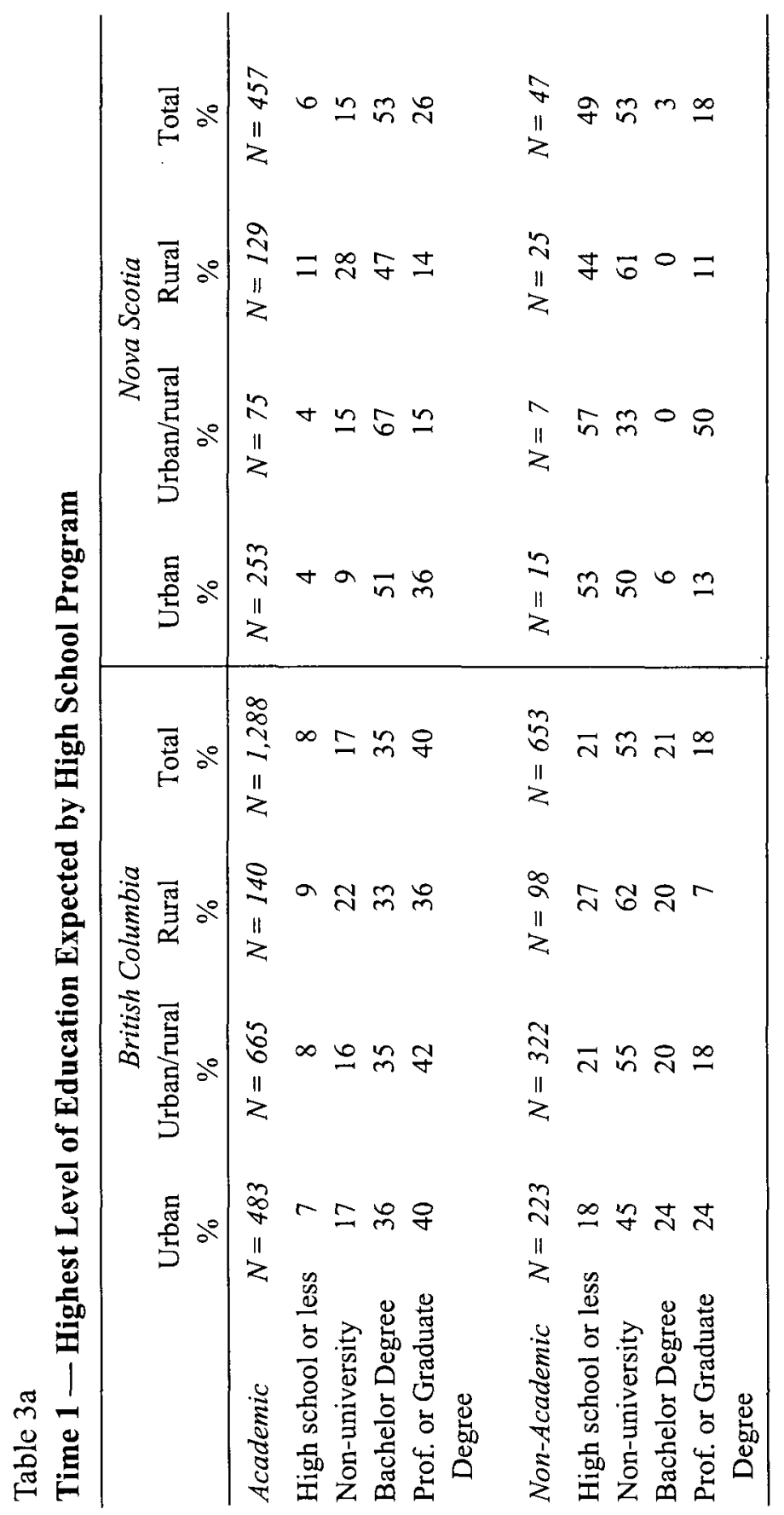

The Canadian Journal of Higher Education

Volume XXXI, No. 2, 2001 


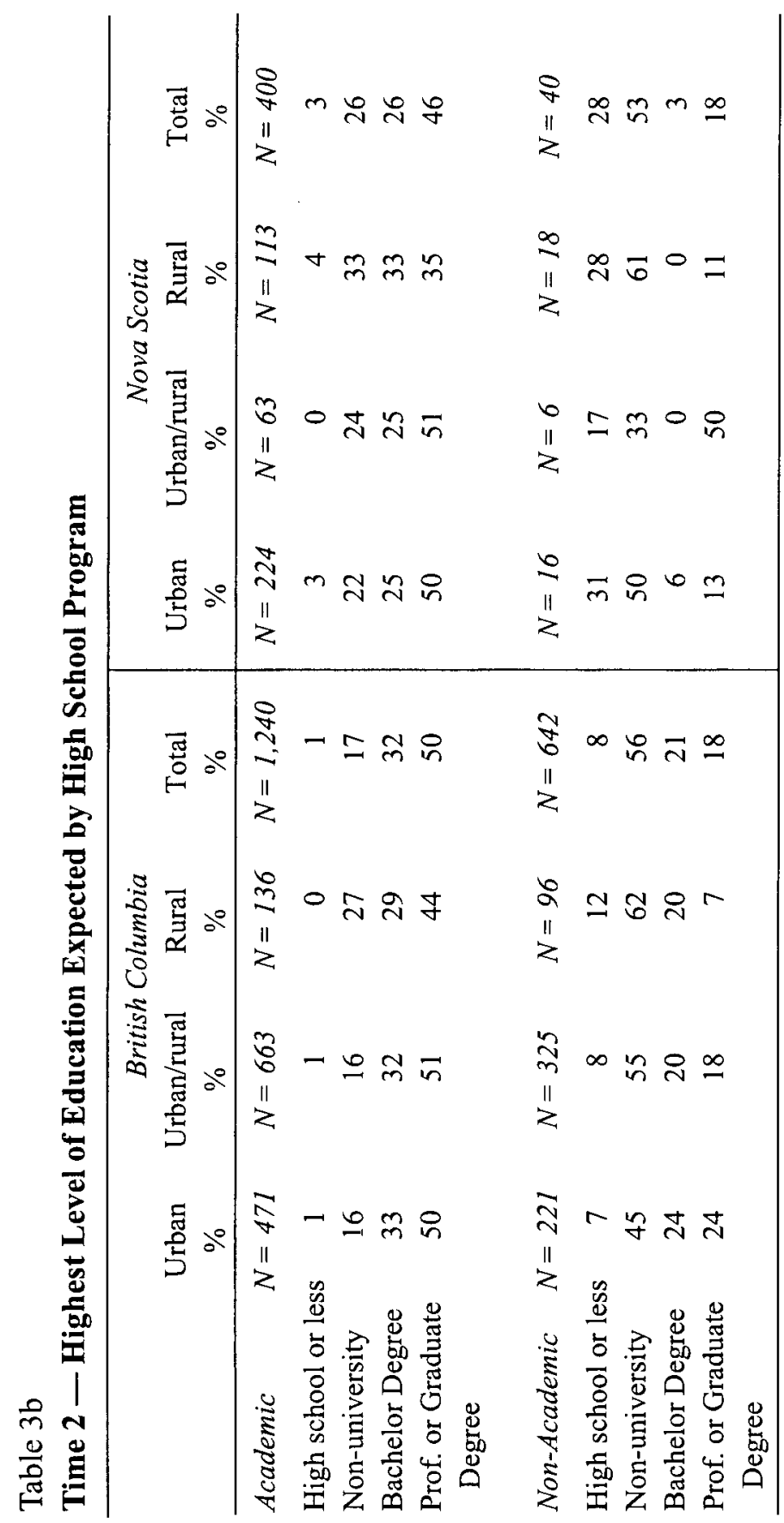

The Canadian Journal of Higher Education Volume XXXI, No. 2, 2001 


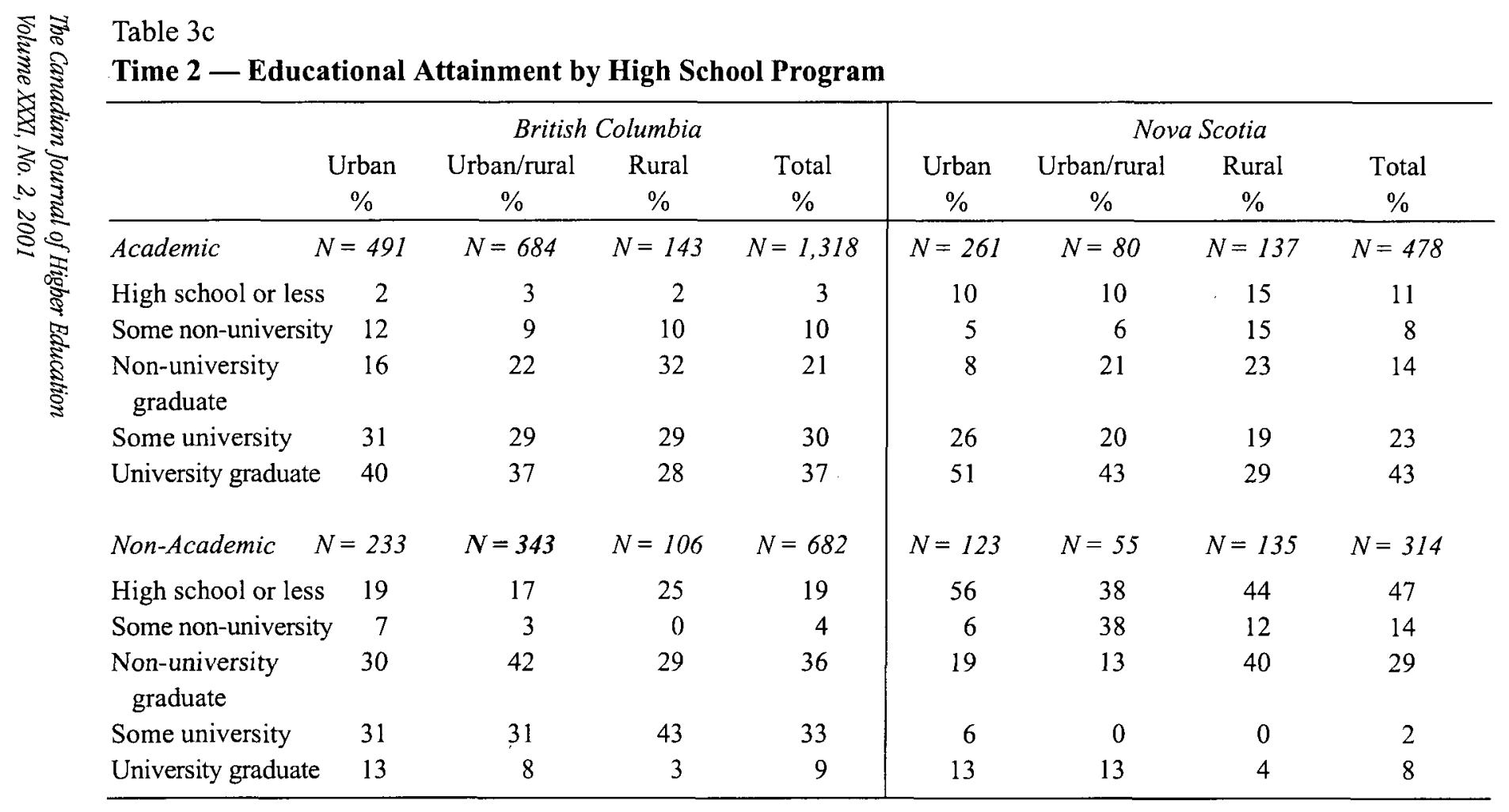

Some university

University graduate

Non-Academic $\quad N=233$ 
(Table 3b). They are more likely to expect to attend non-university institutions than their more urbanized counterparts. The pattern in these expectations is again reflected in their educational attainments (Table 3c). Rural youth are less likely than others to attend university, regardless of their academic program. The only exception to this statement is found for rural B.C. youth in non-academic programs; they are as likely (46\%) as metropolitan (44\%) and urban/rural (39\%) youth to have completed at least some university education by the time of the second survey. However, they are much less likely to have graduated from university.

Comparing across sample sites, we see that the pattern of more Nova Scotia youth completing university degrees holds for almost all subgroups and for both programs. Only in the rural areas do we see that Nova Scotia academic students complete university in the same numbers as their academic counterparts in British Columbia. Also, non-academic students from metropolitan and rural areas in B.C. and N.S. have similar university completion rates.

More important is the fact that despite regional and subregional variations in enrolment in academic as compared to non-academic courses in high school, geographic location continues to have an impact on educational expectations and attainments once program is controlled. It appears not simply to be a matter of rural youth not having the credentials to pursue postsecondary education.

\section{Gender}

Tables $4 \mathrm{a}, 4 \mathrm{~b}$, and $4 \mathrm{c}$ portray the pattern of expectations and attainments for males and females separately. It is interesting that in Nova Scotia, but not in British Columbia, the young women have higher expectations than the young men. In both time periods, more of the Nova Scotia women expect to attend university and to get degrees beyond the undergraduate level. More of the Nova Scotia men compared to the women, in both time periods, expect to attend non-university institutions.

Is the effect of geographic location on expectations and attainments different for young women than it is for young men? The data suggest not - the same pattern that we have seen in the previous three tables is evident in this table as well. Rural youth, both male and female, are less 


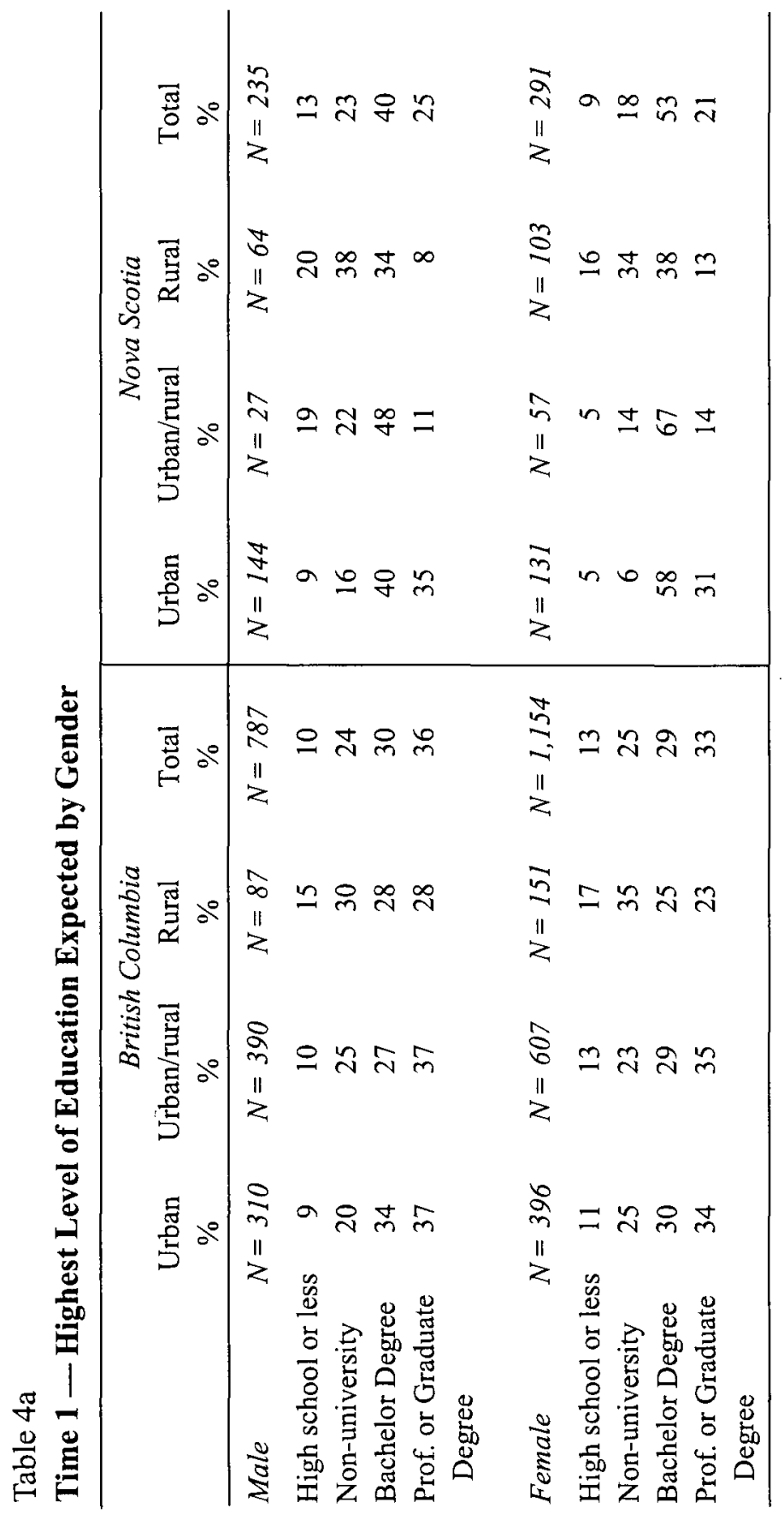

The Canadian Journal of Higher Education

Volume XXXI, No. 2, 2001 


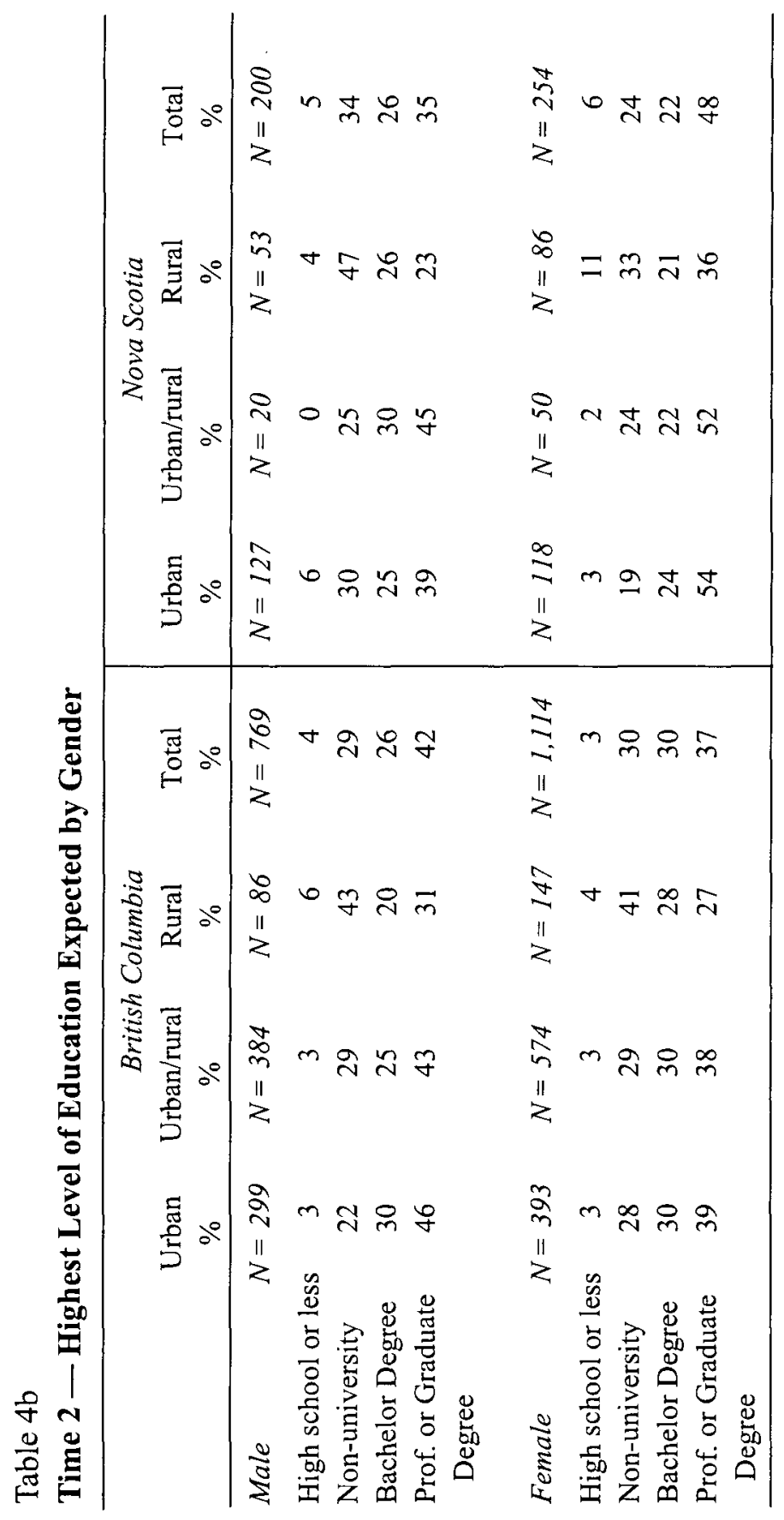

The Canadian Journal of Higher Education Volume XXXI, No. 2, 2001 


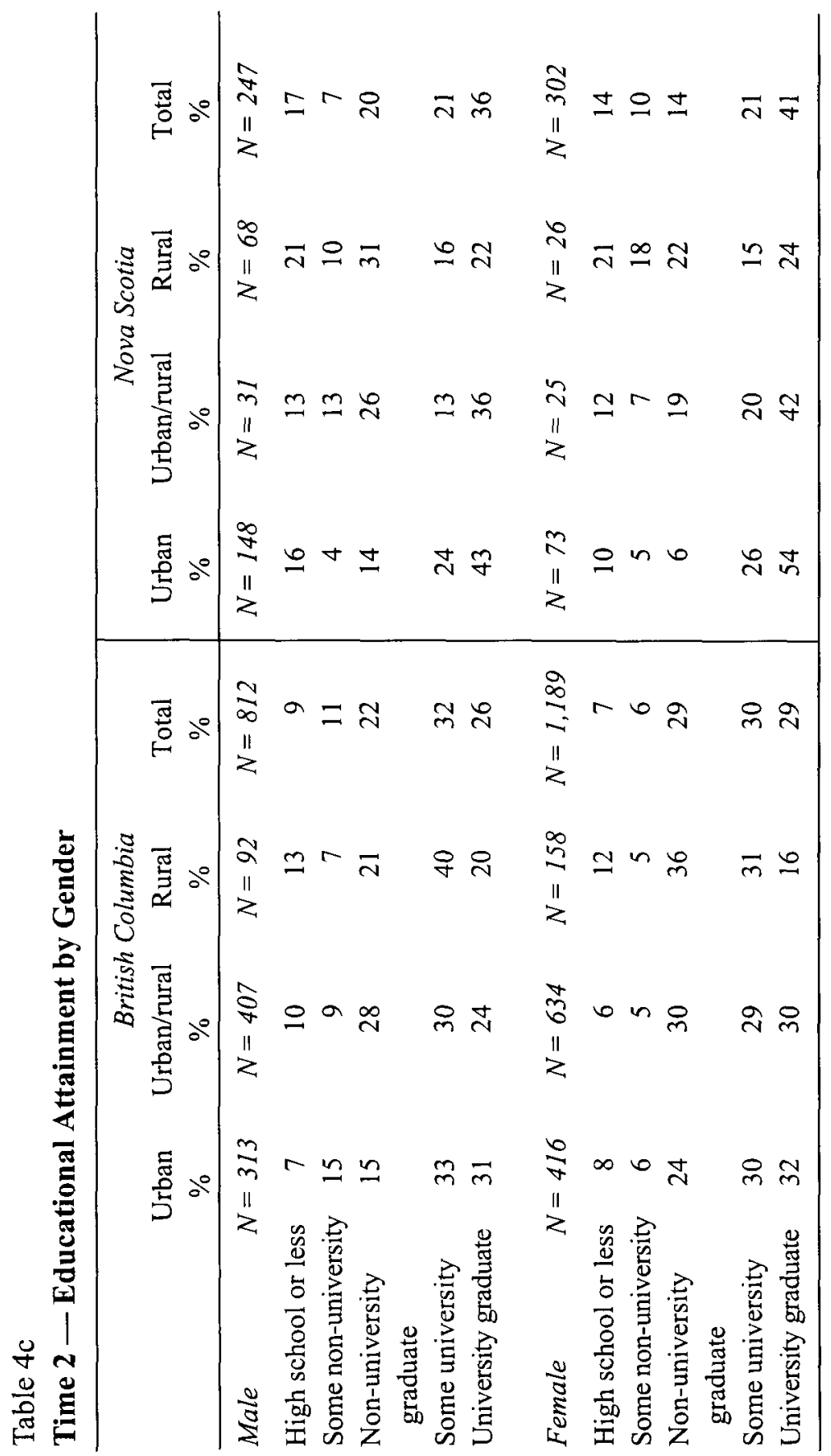

The Canadian Journal of Higher Education

Volume XXXI, No. 2, 2001 
likely to expect to attend university; they are less likely to expect to pursue professional or postgraduate degrees; they are more likely to expect to attend non-university postsecondary institutions. This pattern holds regardless of whether the measure of expectations is taken at time one when they are enroled in or recently graduated from high school, or Time 2 (as many as five years after high school), as Tables $4 \mathrm{a}$ and $4 \mathrm{~b}$ reveal. The expectation patterns for urban/rural youth are most often similar to those from metropolitan rather than those from rural areas.

Finally, Table $4 \mathrm{c}$ presents the educational attainments of the young women and men by the time of the second set of surveys. A few notable male-female differences emerge. In B.C., men in rural areas are more likely than their female counterparts to get to university, and a slightly higher proportion of this group has earned university degrees. However, more women from urban/rural areas in British Columbia complete university. Since rural youth have to leave their home community to attend a postsecondary institution, this might suggest that the men are more mobile than the women. In Nova Scotia, approximately equal numbers of rural females and males attend university; however, more metropolitan and urban/rural females in the N.S. sample attend and complete university.

There are some variations in the specific patterns of educational attainment, and there is differential sample attrition for males and females in the different areas. Nevertheless, the overriding patterns are robust enough to persist. For both males and females, in both regions of the country, rural youth are more likely to have stopped their education after completing high school. For both males and females, the attainments of the urban/rural youth are more like the metropolitan youth than their rural counterparts.

In B.C., rural males are more likely and rural females are just as likely as their metropolitan or urban/rural counterparts to have attended university. However, the university graduation rates of rural and urban/rural males are lower than those of youth living in less rural areas. Females from rural areas are half as likely as their metropolitan and urban/rural counterparts to have completed university. For both women and men, Nova Scotia youth are more likely than the British Columbia respondents to have graduated from a university by the time of the 
second survey. The only exception to this pattern is for rural males; the Nova Scotian rural males are no more likely than their B.C. counterparts to have university degrees.

The next step is to establish the simultaneous effect of the different independent variables we have examined (geographic location, parental education, gender, and academic stream) on the educational expectations and attainments of the youth in the two educational systems. An ordinary least squares regression allows for this simultaneous control. In Table 5, we present three regressions. The first uses Time 1data to identify the influence of the rurality and the other independent variables on Time 1 expectations. The second and third regressions repeat this analysis, using Time 2 data plus the relevant information on Time 1 expectations. ${ }^{11}$ In the second regression, Time 2 expectations serve as the dependent variable. In the third regression, the dependent variable is postsecondary completion status at Time 2, and the effects of all independent variables, including Time 1 and Time 2 expectations are the focus of this analysis.

The first panel of Table 5 documents the effects of the independent variables on youths' educational expectations at Time 1. The important point to note is that non-rural respondents (metro and urban/rural) are statistically significantly different from those from the rural areas (the omitted category).

The second panel of the table, focusing on educational expectations at Time 2, takes into account the effects of the independent variables, including expectations at Time 1 . Given the presence of Time 1 expectations in the equation, the direct effect of location appears weaker. It is interesting to note that, even after the effect of location via these earlier expectations is taken into account, there is still an effect of location on Time 2 expectations. In B.C. the metropolitan respondents are significantly different from the rural ones; in Nova Scotia, the difference is between the urban/rural and the rural youth. However, it is important to note the relatively strong, statistically significant effect of Time 1 expectations, as evident in the betas of .37 in B.C. and .33 for N.S.

In the final section of the table, which includes the effects of both sets of expectations on educational attainments, a further variation on this pattern emerges. At this stage, the only statistically significant 
Table 5

Regression of Expectations at Time 1 and Time 2 and Postsecondary Completion Status at Time 2 on Independent Variables, by Province

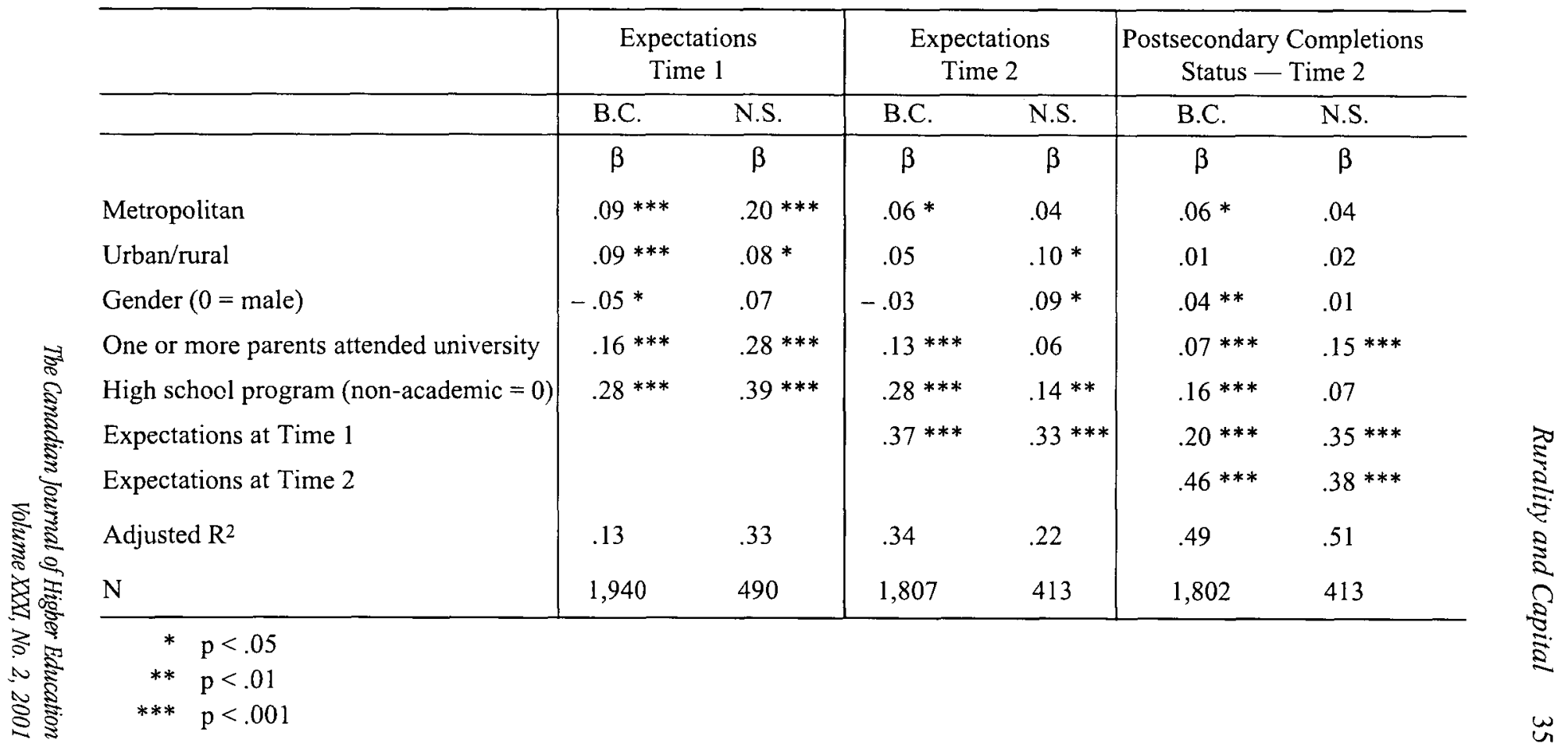


difference for the measures of geographic location is the difference between metropolitan and rural youth in B.C. Again, the strongest effects are for expectations - at both Time 1 and Time 2.

Overall, this set of regression analyses illustrates that living in a rural community influences educational expectation; in turn, expectations have a strong effect on educational attainments. Even taking into account these expectations, and other influences such as parental education, gender and academic stream, rurality still has an effect on attainments in B.C. In other words, we can be confident that the patterns we identified in Tables 1 through 4 are not artifacts of differences in social class, gender or academic preparedness among the different sub-regions of the two provinces.

\section{DISCUSSION}

From the perspectives of equality of opportunity and equality of results, the issue of access to and participation in postsecondary education by disadvantaged groups requires constant vigilance. Despite considerable expansion and diversification of the postsecondary system since the $1950 \mathrm{~s}$, few studies document the extent to which these changes have had an impact on participation and completion patterns of youth from rural and metropolitan areas. In this paper, we have employed longitudinal data of Nova Scotia and British Columbia youth to examine whether expectations at two points in time, and actual educational attainments differed by geographic location.

Overall, consistent patterns emerge throughout this analysis. Clearly, living in a rural area appears to influence perspectives and outcomes, with rural youth having lower educational expectations and attainments than other youth. Measures of educational expectations at Time 1 in this study provide some insight into the educational leanings of respondents either before (Nova Scotia) or early into (British Columbia) their posthigh school lives. In both sample sites, and controlling for gender, academic program, and parental education, rural youth held lower educational expectations. Furthermore, expectations and educational 
attainments measured four or five years following high school graduation reveal that the effects of rurality persist over time.

Although it is the case that, regardless of geographic location, children from families where one or more parent has attended university, and those who graduated from academic programs in high school both have higher expectations and levels of attainment, it is not simply a matter of differences in the amount of cultural capital that rural youth possess. Our findings indicate that a separate "geographic location" effect compounds these cultural reproductive forces. This pattern holds for women as much as for men.

We are left with the question of what it is about rural location that so constrains the educational expectations and attainments of young people. Is it simply a question of lack of availability of postsecondary offerings in rural communities? The need to expand postsecondary opportunities in British Columbia was articulated in a 1962 report that dramatically altered the postsecondary system of this province. Based on the claim that "the dearth of educational opportunity in the interior of the Province means that an important stimulus is missing" (p. 21), Macdonald's (1962) vision for the B.C. postsecondary system led to the establishment of the community college system with university transfer offerings. In turn, this structural change did indeed lead to increased participation rates by those, who by virtue of their geographic location, had been "previously disenfranchised" (Dennison \& Gallagher, 1986, p. 162). Such institutional availability has affected the expectations and attainment levels of B.C. urban/rural youth reported in this study. Individuals in rural areas with access to university-level courses (which we have labeled "urban/rural") expect and obtain university-level education in numbers similar to those in more metropolitan areas. Throughout the analysis, we point out that expectation and attainment patterns for urban/rural youth most closely resemble those of metropolitan youth. Unlike their metropolitan counterparts, however, they do not necessarily take the next step and graduate with a university degree. Moreover, our results demonstrate that this expanded system still does not provide equal opportunities for participation by youth living in the more remote areas of the province. 
Overall, Nova Scotia youth were less likely than their B.C. counterparts to participate in postsecondary education. However, those who did attend were more likely than B.C. postsecondary participants to earn a university degree. It could be argued that the non-articulated nature of the Nova Scotia postsecondary system may pose an initial barrier to access, particularly for rural youth. However, those who did enroll in university following high school were more likely to earn a degree in a shorter period of time. Conversely, the B.C. system may promote the opposite. In other words, in terms of equality of results, Nova Scotia youth fared quite well. Despite an articulated system which allows for transfer credit from the more regionally accessible community colleges to university, British Columbia can boast fewer university graduates among its non-metropolitan (including urban/rural) population than does Nova Scotia. Although overall participation in postsecondary education was extremely high, high non-completion rates by those who have attended university may reflect some of the unintended consequences of inter-institutional transfer as conceptualized by Dougherty (1987) and confirmed empirically by Andres (1998) and Andres, Qayyum, \& Dawson (1997). These include credit loss suffered in the transfer process, lack of meaningful information about the transfer process, declines in grades, and problems becoming socially integrated into the new institution.

These findings raise several challenges for educational policy, both at the secondary and postsecondary levels. First, we suggest that the role of school personnel in relation to promoting postsecondary attendance be examined since adolescents spend a large proportion of their time in the institution called "high school." Given the absence of resources (such as the presence of a postsecondary institution) in rural communities, do rural school personnel consider it part of their professional responsibility to assist students to gain access to the postsecondary system? Are additional resources, such as increased access to the world wide web, provided to schools in rural areas to help students explore post-high school options? In turn, how do rural students perceive their postsecondary options? How do their perceptions differ from those of metropolitan and urban/rural youth? 
Little attention in the access debate has focused on the concept of "rurality." Typically it is defined as "non-urban," primarily on the basis of population density. However, rurality extends beyond this definition. Communities present different conditions of existence which act as a collective set of dispositions (Bourdieu, 1977) through which individuals internalize the same objective structures. Hence, these collective dispositions are partly responsible for forming the lens through which individuals "see" society. Is the concept of rurality the opposite of "citification" which, according to O'Neill (1981), is obtained through proximity to metropolitan centres and exposure to urban resources and ideals? Indepth research from a qualitative perspective could help answer such questions related to the "rurality effect" and how it influences young people's decisions about postsecondary participation.

Our findings also raise questions about how the structure of the postsecondary system in both British Columbia and Nova Scotia facilitates or hinders postsecondary completion. Proponents of articulated postsecondary systems, such as that in British Columbia, claim that community colleges have a "democratizing"effect by offering university-equivalent courses along with lower tuition fees, flexible admission requirements, and programs located within commuting distance and they provide access to individuals with less privileged backgrounds to pursue postsecondary studies, including university degree completion. However, critics of the community college system allege that statistics such as these and findings of other studies on transfer demonstrate that community college attendance is far from democratizing; on the contrary, students are said to be "diverted" away from university study. Our results demonstrate that, for this sample of 1988 high school graduates, in terms of equality of opportunity, the B.C. system is democratizing in that the overwhelming majority do participate in some form of postsecondary study. However, lower university completion rates in all geographic regions in B.C. compared to N.S. suggest the need to monitor students from high school through the postsecondary system to determine barriers - both individual and structural - to degree completion. Unlike Nova Scotia where the policy focus should be on initial access to postsecondary institutions, British Columbia should direct its attention to issues of 
retention. In terms of research and practice, educators need to understand the effects of structure on access and completion.

Finally, should low participation and completion rates by rural youth necessarily be considered problematic? Or does living in a rural environment preclude the necessity to accumulate capital in the form of educational credentials? Surely, the answer to this question will differ depending on which perspective one adopts. An examination of returns of various forms of education by geographic location using the theory of economic rationality would demonstrate the value of investment in higher education. Analyses from a quality of life perspective may indeed portray a very different picture.

\section{Notes}

1 A university in a smaller urban/rural centre in northern British Columbia opened its doors to students in 1993; hence, this institution was not available for the 1988 high school graduates included in this analysis.

2 An exception to this statement is found in the formal arrangement whereby until very recently (when the Teacher's College formally closed), universities in Nova Scotia accepted transfer credit of courses offered at the Nova Scotia Teacher's College, a non-degree granting institution.

3 There was a third part of the study which involved a sample of youth from Hamilton, Ontario, in central Canada. These respondents were excluded from the current analysis in order to hold constant the type of post-secondary options available to the youth. Ontario has a very different post-secondary system than does Nova Scotia.

4 In both the Nova Scotia and British Columbia studies, very similar patterns of sample attrition occurred. That is, less academically-oriented students and males were somewhat more likely to drop out of the study over the years. In the instance of higher attrition on the part of lower achieving respondents, our results may provide over-estimates of postsecondary participation and completion. By systematically examining gender differences in this study, we compare postsecondary participation patterns among male and female respondents, while remaining vigilant of the possibility of bias due to a gendered pattern of attrition. 
5 The Nova Scotia youth were asked to describe how cities and rural areas differ. Both rural and urban youth described the urban areas as places with "more" - more jobs, more action, more opportunities, more fun, but also more crime, more pollution, more violence.

6 The labels "urban," "urban/rural," and "rural" are more consistently used in the literature. However, in this study, the most "urban" category is truly metropolitan in nature. We have chosen the label "metro" to more accurately reflect this category of individuals.

7 This variable could be further broken down into more discrete categories (e.g., "some non-university," "some university"). However, using multiple categories results in very small cell sizes, and hence findings become difficult to interpret.

8 These overall inter-provincial differences in expectations at Time 1 are statistically significant.

9 The universities in in the urban/rural areas of Nova Scotia do not themselves offer graduate degrees, although they do offer access to post-baccalaureate degrees in education. In British Columbia, university colleges offer undergraduate degrees only. As of 1993, graduate programs were available only at five public universities in British Columbia, all except one of which are located in metropolitan areas (see footnote 1).

10 As was found in Table la, the inter-provincial differences in Table 1c are statistically significant. The patterns in Table $1 \mathrm{~b}$, while consistent in direction, were weaker and not statistically significant. In the remaining cross-tabulation tables, the Ns are too small to use statistical significance as the sole test of a relationship. Instead, we will focus on consistency in patterns.

11 Because regression analyses use list-wise deletion of missing cases, the regressions were run separately to maximize the number of cases available. All those who responded to the relevant variables at Time 1 are included in the first equation; those who responded to the relevant questions at Time 2 are in the second and third. 


\section{References}

Alberta Advanced Education. (1984). Participation patterns study. Report of the committee to examine participation trends of Alberta postsecondary students. Edmonton, AB: Alberta Advanced Education, Planning Secretariat.

Allen, R. (1997). The demand and supply of postsecondary education and training in British Columbia. Vancouver, BC: Western Research Network on Education and Training.

Andres, L. (1995). Class of 1988. Grade 12 follow-up five years later. Research report for the British Columbia Council on Admissions and Transfer.

Andres, L. (1998). Investigating transfer project. Phase II. Community college students' perceptions of transfer. Research report prepared for the B.C. Council on Admissions and Transfer.

Andres, L. (1993). Life trajectories, action, and negotiating the transition from high school. In P. Anisef \& P. Axelrod (Eds.), Transitions: Schooling and employment in Canada, (pp. 137-157). Toronto, ON: Thompson Press.

Andres, L., Anisef, P., Krahn, H., Looker, D., \& Thiessen, V. (1999). The persistence of social structure: Class and gender effects on the occupational aspirations of Canadian youth. Journal of Youth Studies, 2(3), 261-282.

Andres, L. \& Krahn, H. (1999). Youth pathways in articulated postsecondary systems: enrolment and completion patterns of urban young women and men. The Canadian Journal of Higher Education, 19(1), 47-82.

Andres, L., Qayyum, A., \& Dawson, J. (1997). Investigating transfer project. Phase I: the transfer experiences of students from community college to university. Research report for the British Columbia Council on Admissions and Transfer.

Anisef, P. (1980). Is the die cast? Educational achievements and work destinations of Ontario youth. Toronto, ON: Ministry of Colleges \& Universities.

Anisef, P., Ashbury, F.D., \& Turrittin, A.H. (1992). Differential effects of university and community college education on occupational status attainment in Ontario. Canadian Journal of Sociology, 17(1), 69-84.

Bourdieu, P.(1977). Outline of a theory of practice (R. Nice, Trans). Cambridge, UK: Cambridge University Press. (Original work published in 1972).

Bourdieu, P.(1986). The forms of capital (R. Nice, Trans). In J.C. Richardson (Ed.), Handbook of theory and research for the sociology of education, (pp. 241-258). New York, NY: Greenwood Press. (Original work published in 1973). 
Bourdieu, P., \& Passeron, J. (1979). The inheritors (R. Nice, Trans). Chicago, IL: University of Chicago Press. (Original work published in 1966).

Breneman, D.W., \& Nelson, S.E. (1981). Financing community colleges: An economic perspective. Washington, $\mathrm{DC}$ : Brookings Institute.

Christie, B.D. (1997). Higher education in Nova Scotia: Where past is more than prologue. In G. Jones (Ed.), Higher education in Canada: Different systems, different perspectives, (pp. 221-244). New York, NY: Garland Publishing, Inc.

Cobb, R.A., McIntire, W.G., \& Pratt, P.A. (1989). Vocational and educational aspirations of high school students: A problem for rural America. Research in Rural Sociology, 6(2), 11-15.

Commission on the Future Development of the Universities of Ontario. (1984). Ontario universities: Options and futures. Toronto, ON: Government of Ontario.

Conroy, C. (1997). Influences on career choice of rural youth and resulting implications for career development programming: When job awareness and exploration are not enough. Journal of Vocational Educational Research, 22(1), 3-19.

Dennison, J.D., \& Gallagher, P. (1986). Canada's community colleges. A critical analysis. Vancouver, BC: The University of British Columbia Press.

Donaldson, G.A. (1990). Do you need to leave home to grow up? The rural adolescent's dilemma. Research in Rural Education, 3(3), 121-125.

Dragastin, S., \& Elder, G. Jr. (1975) (Eds.) Adolescence in the life cycle. Psychological change and social context. Washington, DC: Hemisphere.

Dwyer, P.J. (1995). Post-compulsory education in Australia and the domination of truth. Journal of Educational Policy, 10(1), 95-105.

Dwyer, P.J., Harwood, A., Poynter, G., \& Tyler, D. (1997). Participant pathways and outcomes in vocational education and training. Youth Research Centre, Melbourne, Australia.

Fortin, M. (1987). Accessibility to and participation in the postsecondary education system in Canada. Saskatoon, SK: National Forum on Postsecondary Education.

Guppy, N. (1988). Accessibility to higher education -- New trend data. CAUT Bulletin, 35(6), 15-16.

Guppy, N., \& Pendakur, K. (1989). The effects of gender and parental education on participation with postsecondary education in the 1970 s and 1980s. The Canadian Journal of Higher Education, 19(1), 49-62. 
Haller, E.J., \& Virkler, S.J. (1993). Another look at rural-nonrural differences in students' educational aspirations. Journal of Research in Rural Education, 9(3), 170-178.

Hanson, T.D., \& McIntire, W.G. (1989). Family structure variables as predictors of educational and vocational aspirations of high school seniors. Research in Rural Education, 6(2), 39-49.

Hektner, J.M. (1995). When moving up means moving out: rural adolescent conflict in the transition to adulthood. Journal of Research in Rural Education, $11(1), 3-14$.

Looker, E.D. (1993). Interconnected transitions and their costs: gender and urban/rural differences in the transition to work. In P. Anisef \& P. Axelrod (Eds.), Transitions: Schooling and employment in Canada, (pp. 43-64). Toronto, ON: Thompson Educational Publishing, Inc.

Looker, E.D., \& MacKinnon, D. (1997). Transitions beyond high school: The process and its meaning for rural youth. Paper presented to the National Conference on Rural Education, Saskatoon, SK, February 19, 1997.

Macdonald, J.B. (1962). Higher education in British Columbia and a plan for the future. Vancouver, BC: The University of British Columbia.

McCall, L. (1992). Does gender fit? Bourdieu, feminism, and the conceptions of social order. Theory and Society, 26(6), 837-879.

McCracken, J.D., \& Barcinas, J.D.T. (1991). Differences between rural and urban schools, student characteristics, and student aspirations in Ohio. Journal of Research in Rural Education, 7(2), 29-40.

O'Neill, G.P. (1981). Postsecondary aspirations of high school seniors from different socio-demographic contexts. The Canadian Journal of Higher Education, $11(2)$, 49-66.

Pike, R. (1970). Who doesn't get to university... and why. A study of accessibility to higher education in Canada. Ottawa, ON: Runge Press Ltd.

Porter, J., Porter, M. \& Blishen, B., Barrados, M., Gilbert, S., McRoberts, H., \& Russell, S. (1982). Stations and callings. Toronto, ON: Methuen Publications.

Report of the Provincial Access Committee. (1988). Access to advanced education and job training in British Columbia. Victoria, BC: Ministry of Advanced Education and Job Training.

Sarigiani, P.A., Wilson, J.L., Petersen, A.C., \& Vicary, J.R. (1990). Selfimage and educational plans of adolescents from two contrasting communities. Journal of Early Adolescence, 10, 37-55. 
Schonert, K.A., Elliott, J.P., \& Bills, D.B. (1991). Rural Iowa youth: A descriptive summary of postsecondary persistence five years after high school. Research in Higher Education, 32(3), 269-288.

Sewell, W.H., \& Orenstein, A.M. (1965). Community of residence and occupational choice. American Journal of Sociology, 70(5), 551-562.

Siemens, L.B. (1965a). Some rural-urban differences between Manitoba high school students. Winnipeg, MB: The University of Manitoba.

Siemens, L.B. (1965b). The influence of selected family factors on the educational and occupational aspiration levels of high school-aged youth. Winnipeg, MB: University of Manitoba.

Stephenson, B. (1982). Closing address. In Council of Ministers of Education, Canada, Postsecondary issues in the 1980s, (pp. 17-58). Proceedings of the CMEC Conference on Postsecondary Education, Toronto, ON.

Van Hook, M.P. (1993). Educational aspirations of rural youths and community economic development: Implications for school social workers. Social Work in Education, 15(4), 215-224. 